\title{
An Experiment and CFD Simulation for the Application of a Wind Power System Combined with Exhaust in Super High-Rise Apartment Buildings
}

\author{
Jung Ha Park ${ }^{1}$, Seol Hui Park ${ }^{1}$, Jung Hoon Ju ${ }^{1}$ and Jin Chul Park ${ }^{2}$ \\ ${ }^{1}$ School of Architecture and Building Science, Graduate School, Chung-Ang University, Korea \\ ${ }^{2}$ Professor, School of Architecture and Building Science, Chung-Ang University, Korea
}

\begin{abstract}
The aim of this study was to test the application of a wind power system combined with exhaust to a highrise apartment building. The research results can be summarized as follows ; 1) The proposed location of the wind power system was a roof-top exhaust pipe from a dining room and bathroom of a super high-rise apartment. The size of the module for concentrating wind was $500 \mathrm{~mm}$ in diameter and $320 \mathrm{~mm}$ in height (the upper diameter was $400 \mathrm{~mm}$ with Venturi effect inducement). The blade was a combination of a Savonius type and a Darrieus type, and was able to rotate. 2) Simulation results show that when the outdoor wind velocity was $3 \mathrm{~m} / \mathrm{s}$, the wind velocity discharged from the exhaust pipe of the system, combined with the exhaust appeared to increase compared to the wind velocity discharged from the general exhaust pipe $(0.46$ $\mathrm{m} / \mathrm{s})$. In particular, when the outdoor wind velocity increased $(5 \mathrm{~m} / \mathrm{s})$, the wind velocity discharged from exhaust pipe increased more $(0.77 \mathrm{~m} / \mathrm{s})$, and so the proposed system was found to have a wind velocity amplification effect. 3) As for the results of measuring the generation quantity for 13 days by installing the proposed system on an apartment building rooftop $35 \mathrm{~m}$ tall, the Case 3 system (outside air + exhaust wind + wind concentrating device) proposed in the study appeared to have a higher generation quantity than other systems. Specifically, even when there was a low outside wind velocity value, the electrical energy appeared to be high, confirming the exhaust wind concentration effect. Therefore, the wind power system proposed in this study was found to be effective in terms of increasing driving wind velocity, thus resolving the disadvantage of compact wind power generation systems. This study confirms the viability of applying small wind power generation systems to high-rise apartment buildings, which will contribute to reducing greenhouse gas emissions.
\end{abstract}

Keywords: super high-rise apartment buildings; wind power system combined with exhaust; CFD simulation; field test; reduce green house gas

\section{Introduction}

\subsection{Research Purpose}

To solve recent problems such as the lack of urban density and function as landmarks, the number of super high-rise apartment buildings being constructed has increased. However, compared to buildings in general, super high-rise apartment buildings are known to be energy-guzzling, and thus, energy-saving measures are needed. As super high-rise buildings get higher, the wind velocity increases; with inducement of infiltration between buildings, there is an advantageous wind environment for power generation. Nonetheless, it is hard to acquire the minimum wind volume $(3 \mathrm{~m} / \mathrm{s})$

\footnotetext{
*Contact Author: Jin Chul Park, Professor,

School of Architecture and Building Science,

Chung-Ang University, Heukseok-ro 84, Dongjak-gu, Seoul, Korea

Tel: +82-2-820-5261 Fax: +82-2-812-4150

E-mail: jincpark@cau.ac.kr

(Received April 14, 2013 ; accepted February 26, 2014 )
}

required to operate a wind power system on a super high-rise building. More specifically, considering the seasonal changes in wind direction, it is difficult to generate consistent wind volume. Meanwhile, the stack effect incurred in super high-rise apartment buildings and the lack of ventilation are also important issues to be solved.

The aim of this study was to apply a wind power system to a super high-rise apartment building. The authors attempted to solve the problem of lack of wind velocity by combining the exhaust wind inside the building with the wind produced by the existing wind power system. The authors also investigated the amount of wind power generated by the system and the exhaust wind using simulations and actual object application tests, thus, they will verify the applicability of the system. This research will expand the viability of wind power generation in super high-rise apartment buildings. 


\subsection{Research Contents and Method}

The research contents and method are as follows.

1) The exhaust characteristics of a super high-rise apartment building and applicable small wind power system were investigated, and a small wind power system combined with exhaust was designed and produced.

2) The air current distribution chart for the wind power system combined with exhaust was analyzed using a computational fluid dynamics(CFD) simulation.

3 ) Also, by applying the wind power system combined with exhaust to the actual building, the wind velocity and generation quantity were measured to determine the applicability of the wind power system to a super high-rise apartment building.

\section{Review of Previous Research}

Research about applying small wind power systems to buildings began with Park, Jin Chul (2003), who analyzed local wind direction and wind resources around buildings, reviewed the obstacles to applying wind power generators to building, and made various proposals, after conducting basic research concerning the application of wind power generation systems to buildings. However, acquiring a wind environment in a building was the biggest issue. Jeon, Hyun Do (2010) analyzed the elements necessary to apply wind power generation systems to super high-rise buildings. Lee, Dong Yoon (2011), performed an air current analysis for different types of super high-rise buildings, and identified suitable locations and types of buildings to which to apply wind power systems. Also, Kim, Jong Guen (2010) proposed a design to solve problems in the unification of wind power generation and buildings and, by modeling actual buildings, evaluated energy efficiency via mechanical experiments. And Moon, Chang Ho (2010) and Kim, Yong (2010) reviewed and analyzed existing designs, unifying buildings and wind turbines from the perspective of architecture.

Recently, Kim Sung Yong (2011), analyzed air currents according to different kinds of vertical air inlet flues of super high-rise apartment buildings, $\mathrm{He}$ studied the, feasibility of and elements required for wind power generation using exhaust pipes.

In terms of overseas research, L. Ganmbrota (2007) produced a horizontal module to apply a small wind power generation systems to a super high-rise building and was able to produce $131 \mathrm{kWh}$ yearly at $5 \mathrm{~m} / \mathrm{s}$ wind velocity, W. Becker (2009) proved the applicability of a small wind power generation system in the form of an aerofoil combined with PV. According to C.Tong's (2011) research, using $1.6 \sim 1.8 \mathrm{~m} / \mathrm{s}$ of discharged wind velocity from a cooling tower produced $43.8 \mathrm{MWh}$ of electricity per unit annually. In most of the existing research about wind power generation systems in buildings, most are building integrated types. In addition, only basic research into the feasibility of wind power generators as they relate to the outdoor wind environment has been conducted. There have been few studies of wind power systems combined with exhaust, as is proposed in this study.

\section{Design of a Small Wind Power System Combined with Exhaust \\ 3.1 Concept of the Wind Power System Combined with Exhaust \\ The concept of the wind power system combined} with exhaust proposed in the study, as shown exhaust proposed in the study, as shown in Fig.1., combines the exterior air flow (A) blowing at the topmost level of the high-rise building and the exhaust wind (B) coming from the indoor exhaust pipe of the building. The wind power system changed the direction of the air current to the direction of the outside air at the exhaust end first, and concentrated winds (C) on the blade as much as possible to increase the amount of wind. Also, as concentrated outside air ascends, negative pressure occurs on the exhaust side to increase the exhaust effect. Thus, applying wind power to the building can solve the difficulty of obtaining a minimum wind volume.

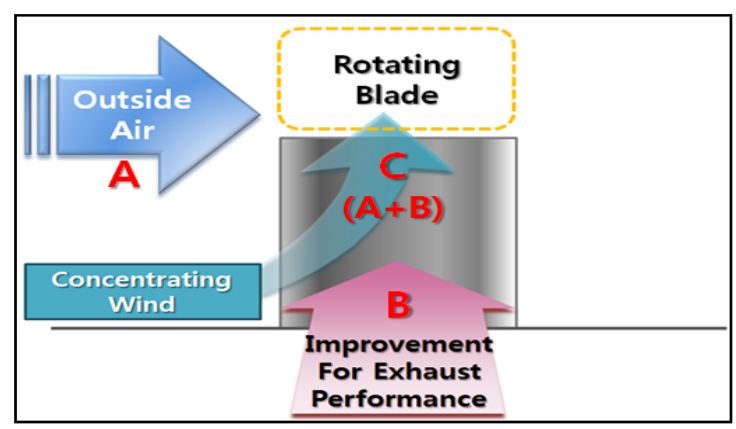

Fig.1. Concept of Small Wind Power System Combined with Exhaust

\subsection{Determining Design Element of the Wind Power System Combined with Exhaust}

(1) Wind speed amplification effect of the Bernoulli effect

For the design of the wind power system combined with exhaust, both the exhaust, effect and the Bernoulli effect, can be used to efficiently operate the wind power generator. That is, the change in pressure that occurs as the external current quickly passes through the narrow structure generates a negative pressure in the exhaust pipe. This in turn generates a strong current with the exhaust effect, and helps create the right environment for windpower generation.

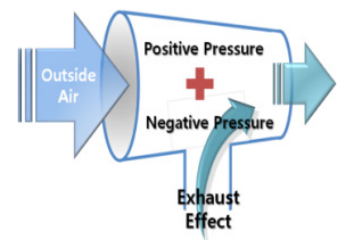

Fig.2. Exhaust using the Bernoulli Effect 
(2) Wind speed amplification effect with separated flow

The external current is not always consistent, so increments of wind speed are required for the operation of the wind power system. As shown in Fig.3., it was found that if the air flow generated by the separated flow of the external current created by the walls and rooftops of high-rise buildings, a strong wind speed necessary for a wind power system could be obtained.

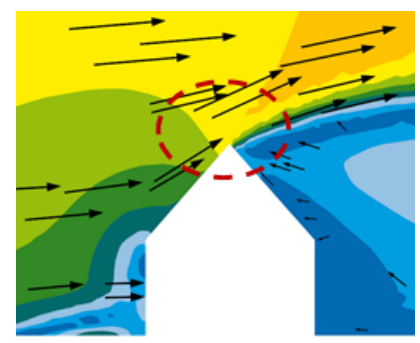

Fig.3. Separated Flow with Increased Wind Velocity

(3) Minimization of turbulence

Another great hindrance in the operation of a wind power system is the reduction of air flow velocity due to turbulence. Therefore, if the occurrence of turbulence can be minimized, the efficiency of the wind power system can be improved. In this study, the authors conducted simulations in order to understand the turbulence phenomena according to the form of the building. Fig.4. shows the results of a simulation of the turbulence occurring in quadrangular and circular buildings. While turbulence occurred widely in the rectangular-shaped building, it was reduced in the circular -shaped building. Therefore, a circular building is advantageous in the application of a wind power system.

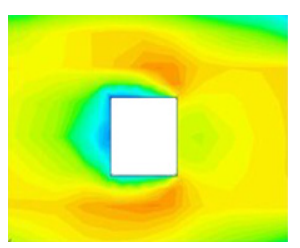

(a) Rectangular shape

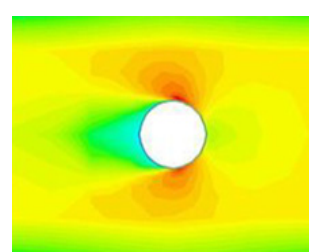

(b) Circular shape
Fig.4. Comparison of Turbulence According to Shape

\subsection{Analysis of Application Location of the Wind Power System Combined with Exhaust}

Exhaust pipes in a super high-rise apartment building that can incorporate the small wind power generation system are the exhaust pipes coming from the dining rooms and bathrooms and the air-flue of boilers and generators. According to Kim Sung Yong et al. (2011), in Korean super high-rise apartment buildings, exhaust pipes in dining rooms and bathrooms are typically about $500 \mathrm{~mm}$ and the air-flues of boilers and generators are about $1,400 \mathrm{~mm} \sim 2,000 \mathrm{~mm}$ (see Table 1.).
Table 1. Exhaust Status of Main Super High-Rise Apartments

\begin{tabular}{|c|c|c|c|c|c|}
\hline & \multicolumn{4}{|c|}{ Name of High-rise Apartment } & \multirow{2}{*}{$\begin{array}{l}\text { Applicability } \\
\text { of wind power } \\
\text { generation } \\
\text { combined with } \\
\text { exhaust }\end{array}$} \\
\hline & $\begin{array}{l}\text { Seoul } \\
\text { "T" }\end{array}$ & $\begin{array}{l}\text { Seoul } \\
\text { "C" }\end{array}$ & $\begin{array}{l}\text { Busan } \\
\text { "C" }\end{array}$ & $\begin{array}{l}\text { Busan } \\
\text { "S" }\end{array}$ & \\
\hline Dining room & 800 & 500 & 350 & 400 & o \\
\hline $\begin{array}{l}\& \\
\text { Bath room }\end{array}$ & $\times 500$ & $\times 400$ & $\times 350$ & $\times 600$ & \\
\hline $\begin{array}{l}\text { Boiler } \\
\text { air-flue }\end{array}$ & $\phi 1600$ & - & $\phi 1600$ & $\phi 2000$ & $x$ \\
\hline $\begin{array}{l}\text { Generator } \\
\text { air-flue }\end{array}$ & $\phi 1450$ & - & $\phi 1400$ & - & $x$ \\
\hline
\end{tabular}

Therefore, based on the data analysis, the application location of the proposed wind power system was the exhaust pipes of the dining rooms and bathrooms in the super high-rise apartment building, and the size of the exhaust pipes was about $500 \mathrm{~mm}$.

\subsection{Design of the Wind Power System Combined with Exhaust}

(1) Exhaust pipe design

Based on the previous research, an exhaust pipe for the wind power system was designed. The exhaust pipe was circular to minimize the warm air current from the rear part of the exhaust pipe (see Fig.5.).

The circular structure gathers air currents passing through the guide vane to cause the exhaust wind to ascend to the inside of the exhaust pipe.

Also, as seen in Fig.6., changing the direction of the horizontal air current compared to the vertical wind, increases the wind volume of the ascending air current inside the exhaust pipe.

Hence, air currents entering the exhaust pipethrough the guide vane cause a strong ascending windinside the exhaust pipe due to the Bernoulli effect, which increases the exhaust effect.

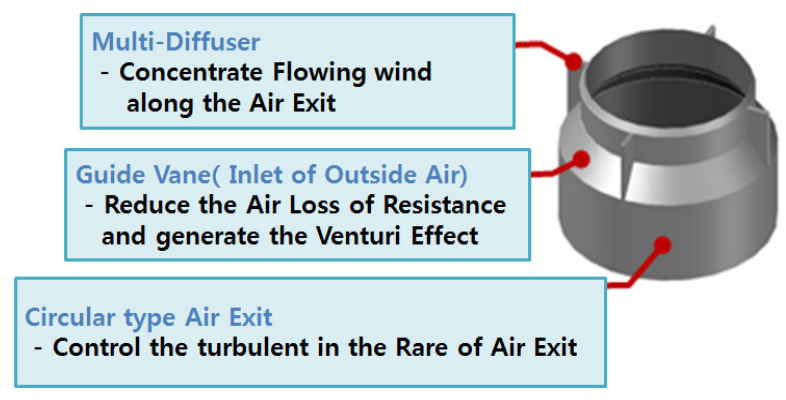

Fig.5. Air Vent Module Design

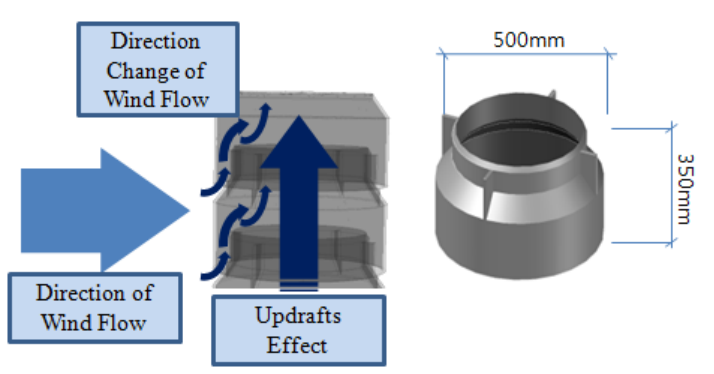

Fig.6. Wind Flow of Air Vent Module 
Based on the analysis of the previous data, it was designed to be $500 \mathrm{~mm}$ in diameter, which was the general size of the dining room and bathroom exhaust pipes, based on the common supply and exhaust method in the super high-rise apartment building (see Fig.7.). To amplify the exhaust wind using the Venturi effect, the upper section was made smaller than the lower section, at $400 \mathrm{~mm}$ in diameter. Also, the exhaust pipes were modularized by being able to be combined with each other, to control the number of modules and, to maximize the wind concentration effect.

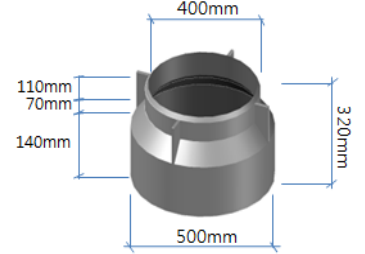

(a) Detail of module

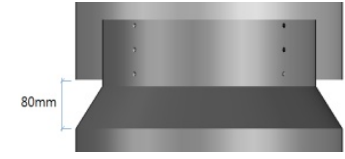

(b) The gap between modules of air vent
Fig.7. Details of Designed Exhaust Pipe

(2) Design of the wind power system combined with exhaust

The blade has the most significant effect on the performance of the wind power system. Blades can be categorized as horizontal or vertical according to the rotation axis of the blade. Based on the blade, characteristics, the small wind power system is suitable for application to the current building (see Table 2.).

Table 2. Examples of Small Wind Power System

\begin{tabular}{|c|c|c|c|c|}
\hline \multirow[t]{2}{*}{ Type } & Horizontal-Axis & \multicolumn{3}{|c|}{ Vertical-Axis } \\
\hline & Propeller & Savonius & $\begin{array}{l}\text { Darrieus \& } \\
\text { Savonius }\end{array}$ & Giromill \\
\hline Rated power & $400 \mathrm{~W}$ & $500 \mathrm{~W}$ & $400 \mathrm{~W}$ & $1 \mathrm{~kW}$ \\
\hline Cut-in Wind & $2.7 \mathrm{~m} / \mathrm{s}$ & $1 \mathrm{~m} / \mathrm{s}$ & $3 \mathrm{~m} / \mathrm{s}$ & $1.3 \mathrm{~m} / \mathrm{s}$ \\
\hline $\begin{array}{l}\text { Speed } \\
\text { Radius of } \\
\text { gyration }\end{array}$ & $1.15 \mathrm{~m}$ & $1.4 \mathrm{~m}$ & $2 \mathrm{~m}$ & $2 \mathrm{~m}$ \\
\hline
\end{tabular}

Because the proposed small wind power generation system generates wind power using both the outside air and exhaust wind, it is a combination of the Savonius and Darrieus types of system. The blade can rotate using the outside wind velocity and the exhaust wind.

\section{CFD Simulation of the Wind Power System Combined with Exhaust \\ 4.1 CFD Simulation Overview}

In this section, the authors analyze the wind environment of the proposed wind power system using a CFD simulation. The system was also compared with general exhaust pipes.

The simulation was conducted using a wind concentrating device for the wind power system and a general circular exhaust pipe for the $500 \mathrm{~mm}$ diameter exhaust pipe (see Table 3. and 4. for details of the exhaust pipe designed and computational grid and boundary conditions).
Table 3. Number of Computational Grids

\begin{tabular}{l|l|l}
\hline & General exhaust & Designed exhaust \\
\hline Cells* & $1,032,114$ & $1,138,603$ \\
\hline Interior Faces* & $3,068,075$ & $3,381,489$ \\
\hline *Cells : Faces of analysis area \\
*Interior Faces : Measurement unit for 3D analysis
\end{tabular}

Table 4. Boundary Condition of CFD Simulation

\begin{tabular}{|c|c|c|c|}
\hline \multicolumn{4}{|c|}{ Boundary condition of CFD simulation } \\
\hline Space & Three-dimensional & Motion & Stationary \\
\hline Material & Gas & Flow & $\begin{array}{l}\text { Segregated } \\
\text { flow }\end{array}$ \\
\hline $\begin{array}{l}\text { Equation of } \\
\text { state }\end{array}$ & Constant Density & Time & Steady \\
\hline Viscous & Turbulent & Wind & $3 \mathrm{~m} / \mathrm{s}$ \\
\hline Regime & \multirow{2}{*}{\multicolumn{3}{|c|}{$\begin{array}{l}\text { K-ETurbulence ( RANS : Reynolds } \\
\text { - Averaged Navier Stokes equations) }\end{array}$}} \\
\hline Equations & & & \\
\hline $\begin{array}{l}\text { Volume } \\
\text { mesh type }\end{array}$ & \multicolumn{3}{|c|}{$\begin{array}{l}\text { Polyhedral Mesher + Prism Layer Mesher + } \\
\text { Extruder }\end{array}$} \\
\hline
\end{tabular}

Thus, outside wind velocity conditions were selected to be $3 \mathrm{~m} / \mathrm{s}$, basic wind velocity of driving small wind power generator and $5 \mathrm{~m} / \mathrm{s}$ considering the wind velocity increase. As shown in Fig.8., wind velocity measurements were taken at 4 spots, including spot (\#1) where the Savonius-type blade was installed, the spot (\#2) where the Darrieus-type blade was installed and the upper section (\#3) inside the exhaust pipe, and the lower section (\#4).

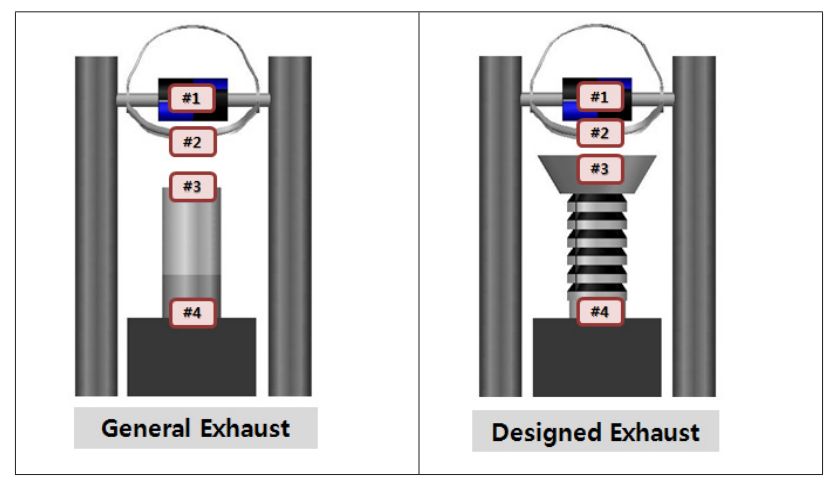

Fig.8. Measurement Points of Wind Speed

\subsection{Simulation Results}

Simulation results are shown in Table 5., Fig.9., Fig.10., Fig.11. and Fig.12.

Table 5. Result of CFD Simulation

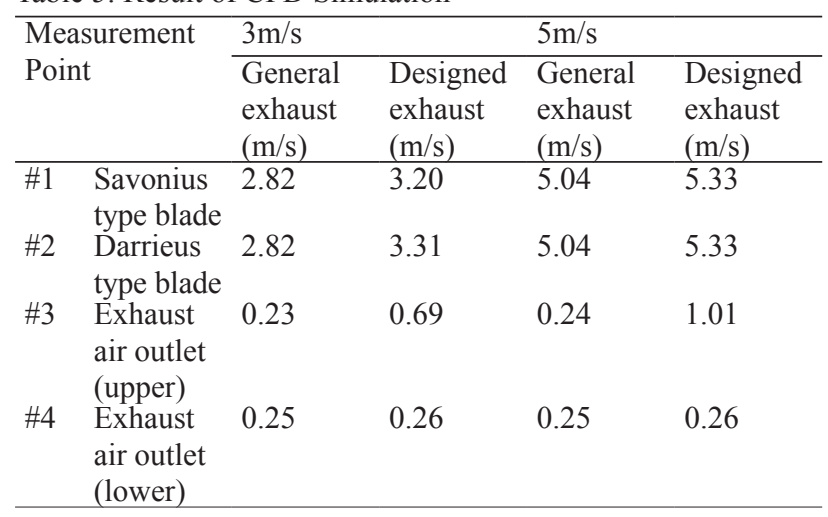




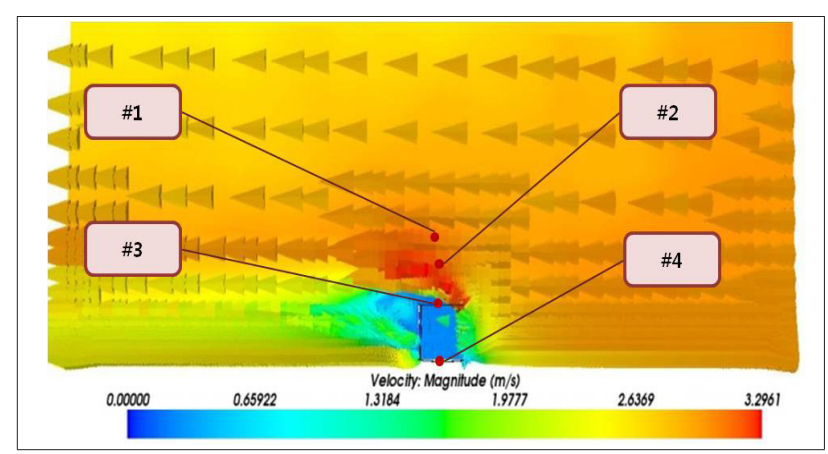

Fig.9. Air Flow of the Wind at 3m/s (General Exhaust)

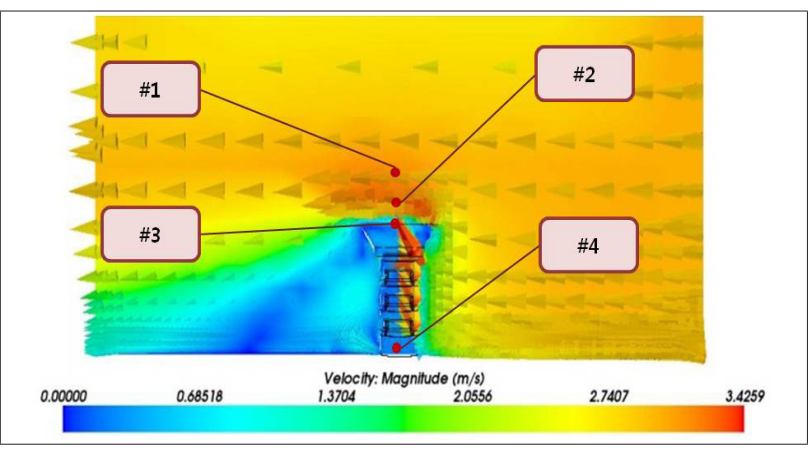

Fig.10. Air Flow of the Wind at 3m/s (Designed Exhaust)

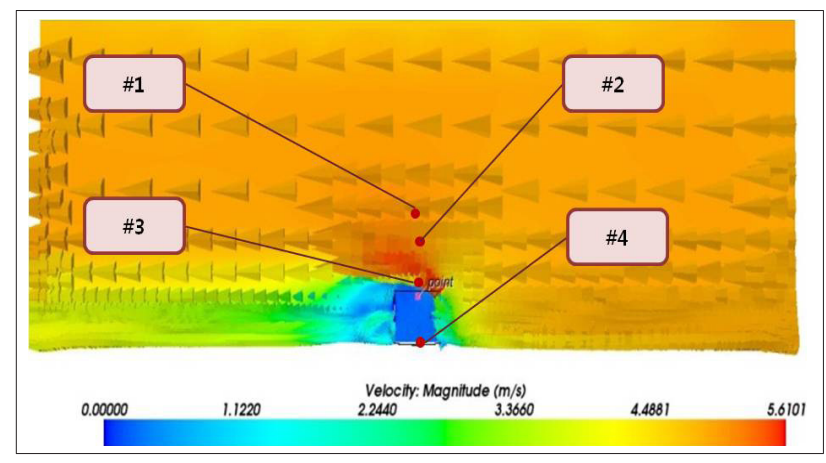

Fig.11. Air Flow of the Wind at $5 \mathrm{~m} / \mathrm{s}$ (General Exhaust)

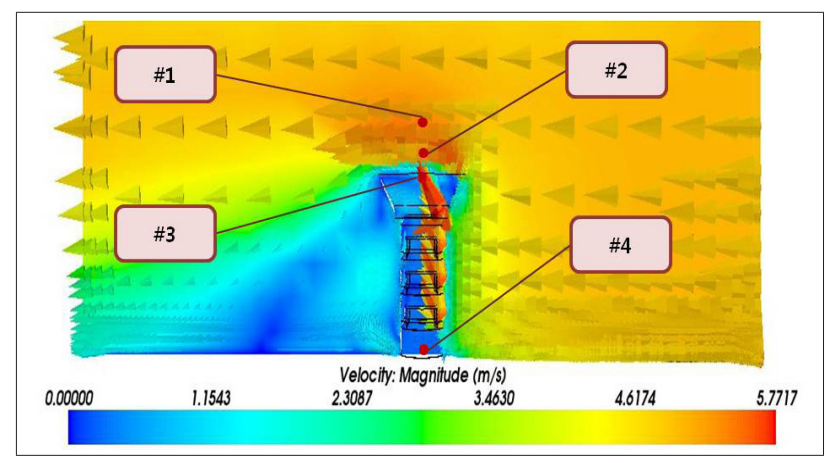

Fig.12. Air Flow of the Wind at $5 \mathrm{~m} / \mathrm{s}$ (Designed Exhaust)

As can be seen in Table 5., when the outside wind velocity was $3 \mathrm{~m} / \mathrm{s}$, the discharge wind velocity of the exhaust pipe combined with the exhaust wind appeared to increase by $0.46 \mathrm{~m} / \mathrm{s}$ compared to that of the general exhaust pipe. When the outside wind velocity was 5 $\mathrm{m} / \mathrm{s}$, the discharge wind velocity of the exhaust pipe combined with the exhaust wind increased by $0.77 \mathrm{~m} / \mathrm{s}$, indicating an exhaust amplification effect. Also, the wind velocity at spot (\#1) where the Savonius-type blade was installed increased by about $0.38 \mathrm{~m} / \mathrm{s}$ when the designed exhaust pipe was installed, assuming an outside wind velocity of $3 \mathrm{~m} / \mathrm{s}$, and appeared to increase by about $0.29 \mathrm{~m} / \mathrm{s}$ when the outside wind velocity was $5 \mathrm{~m} / \mathrm{s}$. Therefore, the proposed small wind power system was found to have a wind velocity increase effect for exhaust wind velocity and wind power generation.

\section{Field Measurement Experiment on Generation Quantity by the Small Wind Power System Combined with Exhaust \\ 5.1 Overview of Field Measurement of Generation Quantity \\ The small wind power generation system was} designed and produced according to the information in sections 3 and 4 . It used the horizontal type to combine exhaust wind power. Also, to increase exhaust wind, a device concentrating wind with air current inducement was added. The experiment was conducted at an apartment building located in Seoul. The building is $35 \mathrm{~m}$ tall and has 12 floors, the system was installed on the rooftop. The experiment was conducted as in Table 6 . in order to make a comparison with the proposed device. Case 1 is a system considering outside air and exhaust wind, and Case 2 is a system combining the designed exhaust pipe, a device concentrating wind with air current inducement to outside air and exhaust wind proposed in the study. Measurements were conducted for 13 days. A monitoring device was used to measure generation quantity for 10 seconds and a meteorological instrument was used to measure wind direction and wind velocity for 10 seconds. The equipment used in the measurement experiment is listed in Table 7.

Table 6. Outline of Experiment Cases

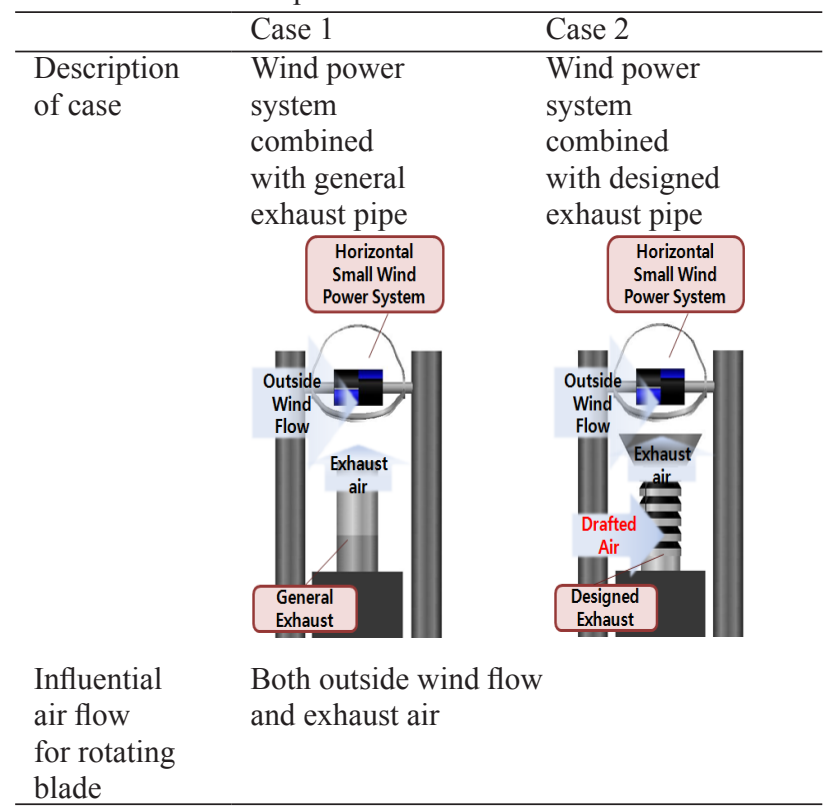


Table 7. Measurement Instrument

\begin{tabular}{lll}
\hline Measurement instrument & Description \\
\hline & $\begin{array}{l}\text { Vantage Pro2 } \\
\text { (weather }\end{array}$ & - Solar powered integrated \\
observation) & Temsor suite : Rain collector, \\
DS Scan 500 & Merature, humidity sensors \\
& & generation
\end{tabular}

\subsection{Field Measurement Results of Generation} Quantity

Generation quantity and the wind velocity measurements based on wind direction and wind velocity are shown in Fig.13., Fig.14., Table 8. and Table 9.

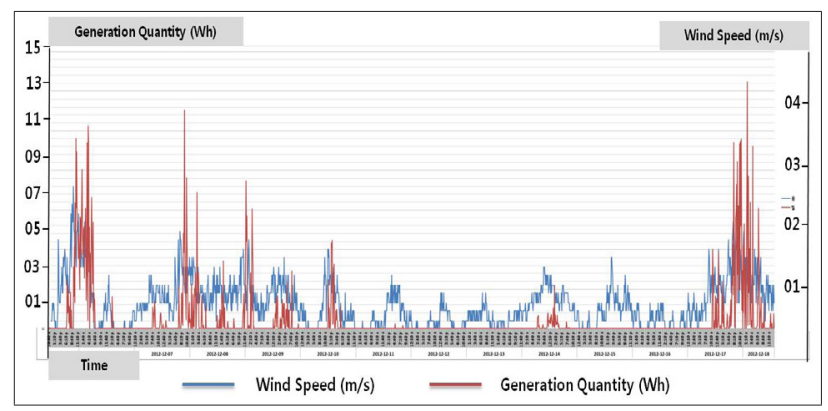

Fig.13. Graph of Wind Speed and Generation Quantity (Case 1)

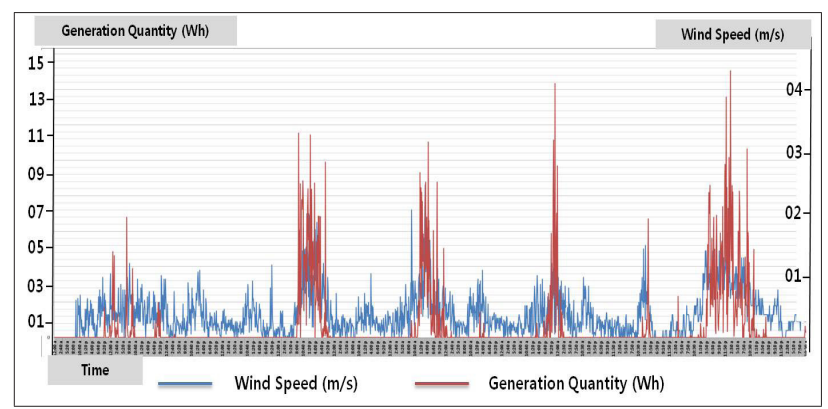

Fig.14. Graph of Wind Speed and Generation Quantity (Case 2)

Table 8. Results of Wind Velocity and Generation Measurement (Case 1)

\begin{tabular}{lllll}
\hline & \multicolumn{3}{l}{ Wind } & \multicolumn{2}{l}{$\begin{array}{l}\text { Daily } \\
\text { generation quantity }\end{array}$} \\
\cline { 2 - 5 } & $\begin{array}{l}\text { Velocity } \\
(\mathrm{m} / \mathrm{s})\end{array}$ & $\begin{array}{l}\text { Wind } \\
\text { direction }\end{array}$ & $\begin{array}{l}\text { Average } \\
(\mathrm{W})\end{array}$ & $\begin{array}{l}\text { Cumulative } \\
(\mathrm{Wh})\end{array}$ \\
\hline Day-1 & 1.1 & SSE & 1.20 & 28.8 \\
Day-2 & 1.7 & $\mathrm{E}$ & 0.50 & 12.0 \\
Day-3 & 2.0 & $\mathrm{NW}$ & 0.37 & 9.0 \\
Day-4 & 1.7 & $\mathrm{NW}$ & 0.52 & 12.5 \\
Day-5 & 0.6 & $\mathrm{NW}$ & 0.24 & 5.8 \\
Day-6 & 0.6 & $\mathrm{NW}$ & 0.00 & 0.1 \\
Day-7 & 0.3 & $\mathrm{NW}$ & 0.00 & 0.0 \\
Day-8 & 0.5 & $\mathrm{E}$ & 0.00 & 0.0 \\
Day-9 & 1.5 & $\mathrm{E}$ & 0.12 & 2.8 \\
Day-10 & 0.9 & $\mathrm{NW}$ & 0.00 & 0.0 \\
Day-11 & 0.4 & $\mathrm{~W}$ & 0.00 & 0.0 \\
Day-12 & 2.0 & $\mathrm{NW}$ & 1.12 & 27.0 \\
Day-13 & 2.3 & $\mathrm{NW}$ & 0.98 & 23.5 \\
\hline Average & $1.7 \mathrm{~m} / \mathrm{s}$ & & $9.33 \mathrm{Wh}$ \\
\hline
\end{tabular}

Table 9. Results of Wind Velocity and Generation Measurement (Case2)

\begin{tabular}{lllll}
\hline & \multicolumn{3}{l}{ Wind } & \multicolumn{2}{l}{$\begin{array}{l}\text { Daily } \\
\text { generation quantity }\end{array}$} \\
\cline { 2 - 5 } & $\begin{array}{l}\text { Velocity } \\
(\mathrm{m} / \mathrm{s})\end{array}$ & $\begin{array}{l}\text { Wind } \\
\text { direction }\end{array}$ & $\begin{array}{l}\text { Average } \\
(\mathrm{W})\end{array}$ & $\begin{array}{l}\text { Cumulative } \\
(\mathrm{Wh})\end{array}$ \\
\hline Day-1 & 0.68 & SW & 0.03 & 0.76 \\
Day-2 & 1.61 & W & 0.38 & 9.19 \\
Day-3 & 1.02 & SW & 0.00 & 0.04 \\
Day-4 & 0.84 & SW & 0.00 & 0.00 \\
Day-5 & 1.91 & WSW & 2.08 & 49.97 \\
Day-6 & 0.82 & SW & 0.00 & 0.00 \\
Day-7 & 2.00 & WSW & 1.39 & 33.27 \\
Day-8 & 1.15 & WSW & 0.03 & 0.74 \\
Day-9 & 1.20 & WSW & 0.66 & 15.92 \\
Day-10 & 1.08 & SW & 0.13 & 3.14 \\
Day-11 & 0.69 & SW & 0.13 & 3.14 \\
Day-12 & 1.89 & W & 1.39 & 33.35 \\
Day-13 & 2.25 & NW & 1.78 & 42.61 \\
\hline Average & $0.87 \mathrm{~m} / \mathrm{s}$ & & $14.77 W h$ \\
\hline
\end{tabular}

The result of this experiment shows that when the mean wind velocity of the wind discharged from the general exhaust pipe (Case 1) was $1.7 \mathrm{~m} / \mathrm{s}$, the amount of wind generated was $9.331 \mathrm{Wh}$ /day. For the designed exhaust pipe (Case 2), the generation occurred at the mean wind velocity of $0.84 \mathrm{~m} / \mathrm{s}$. It was determined that the outside wind flowed into the module and increased the exhaust wind velocity, which generated power. Power was generated at a lower mean wind velocity in the designed exhaust pipe compared to that generated in the general cylindrical exhaust pipe. This seems to be due to the amplification effect of the designed exhaust pipe. The amount of wind generated was $14.774 \mathrm{Wh} /$ day, which was higher by $5.4 \mathrm{Wh} /$ day than that generated in the general exhaust pipe. This shows that the application of the designed exhaust pipe improved the efficiency of the proposed small wind power system.

\section{Conclusions}

The aim of this research was to apply an exhaust wind power generation system to a super high-rise apartment. The aggregated research results are as follows.

1) Most of the previous research concerning wind power generation systems in buildings examined buildings with integrated systems, and only basic research on the feasibility of a wind power generator in the outside wind environment has been conducted. There has been little research on a wind power system such as the one - proposed in this study.

2) The detailed design proposal for our wind power system is as follows: Application locations were rooftop exhaust pipes of dining rooms and bathrooms in a super high-rise apartment building. Module device concentrating wind was installed, and the module was $500 \mathrm{~mm}$ in diameter and $320 \mathrm{~mm}$ high (the upper diameter was $400 \mathrm{~mm}$ for the Venturi effect 
inducement). The blade is a combination of a Savonius type and a Darrieus type, and is able to rotate.

3 ) Simulation results for the proposed system are as follows. When outside wind velocity is $3 \mathrm{~m} / \mathrm{s}$, discharge wind velocity of the exhaust pipe in the proposed system appeared to increase by $0.46 \mathrm{~m} / \mathrm{s}$ compared to the discharge wind velocity of the general exhaust pipe. Specifically, when outside wind velocity increased ( 5 $\mathrm{m} / \mathrm{s})$, the exhaust discharge wind velocity increased more $(0.77 \mathrm{~m} / \mathrm{s})$, which indicates that the proposed system archived a wind velocity amplification effect.

4) The amount of wind generated (measured over 13 days) by installing the proposed compact system on the rooftop of an apartment building $35 \mathrm{~m}$ tall are is as follows. The Case 3 (outside air + exhaust wind + device concentrating wind) system appeared to generate more than Case 1 (outside air) and Case 2 (outside air + exhaust wind) systems. Notably, even though the outside wind velocity was low, the electrical energy appeared to be high, which confirms the exhaust concentrator effect.

Hence, the proposed wind power generation system was effective in increasing driving wind velocity, thus resolving the disadvantages of existing small wind power generation systems. This study confirms the viability of applying small wind power generation systems to super high-rise apartment buildings, which will contribute to reducing greenhouse gas emissions.

\section{Acknowledgements}

This work was supported by the National Research Foundation of Korea (NRF) grant funded by the Korea government (MEST) (No.2010-0027393) and was supported by the Chung-Ang University Excellent Student Scholarship.

\section{References}

1) AG Dutton et al. (2002), The Feasibility of Building/ Integrated Wind Turbines; Archiving their potential for carbon emission reduction.

2) C. H. Moon et al. (2010), A Case Study on the Utilization of Wind Turbine on Urban Building Design, Journal of Architectural Institute of Korea, Vol. 12, No. 4.

3) D. Y. Lee (2011), A Study on the Application of Hybrid Power System in Super Hjgh-rise Building, Chung Ang University Graduate School, Master's Thesis.

4) H. D. Jeon (2010), A Study on the Application of Wind Power System in Super High-rise Buildings, Chung Ang University Graduate School, Master's Thesis.

5) H. J. Jang et al. (2012), A Study on the Application Process of Small Wind Turbine System in Super High-rise Building, Chung Ang University Graduate School, Master's Thesis.

6) H. J. Kang et al. (2012), A Development of Energy Load Prediction Equations for Multi-Residential Buildings in Korea, Journal of Asian Architecture and Building Engineering, Vol. 11, No.2.

7) H. K. Shin et al. (2013), Air Leakage Characteristics and Leakage Distribution of Dwellings in High-rise Residential Buildings in Korea, Journal of Asian Architecture and Building Engineering, Vol. 12, No.1.
8) J. C. Park et al. (2003), A Study on the Application of Small-Sized Wind Power Generation System in Apartment House, Korean Solar Energy Society.

9) J.C. Park et al. (2013), A Study on the Application of Small Wind Power System with Combined Ventilator in Super Highrise Apartment, Journal of Asian Architecture and Building Engineering, Vol. 12, No.1.

10) J. H. Cho et al. (2006), Pressure distribution and problems caused by the stack effect in the High-rise building, Society of AirConditioning and Refrigerating Engineers of Korea, Vol.35, No.5.

11) J. H. Park et al. (2011), A Basic Study on Application of Small Wind Power System Combined Ventilator in Super High-rise Apartment (1), Korean Solar Energy Society Vol.31, No.3.

12) J. K Kim et al. (2010), A Study on the Energy Efficiency of Building-integrated Wind Turbines, Journal of Architectural Institute of Korea, Vol. 26, No. 8.

13) K. Y. Song et al. (2012), Research and Analysis for Developing of Evaluation on the Site Selection of Wind Farm, The Wind Engineering Institute of Korea, Vol.16, No.1.

14) S. Yamada et al. (2005), Study on Environmental Recognition of Super High-rise Housing Residents, Journal of Asian Architecture and Building Engineering, Vol. 4 No.2.

15) S. Y. Kim et al. (2011), A Study on the Vertical Flue Duct for Application of Small Wind Power System in High-Rise Apartments, Korean Solar Energy Society, Vol.31, No.3.

16) W. H. Jeon et al. (2009), CFD Analysis on a Tall Building Augmented Wind Turbine, The Korean Environmental Sciences Society, Vol.18.

17) Y. Suwa et al. (2011), Optimal Airflow Performances for FOUP Systems in Cleanrooms Using SVE Quantification Method, Journal of Asian Architecture and Building Engineering, Vol.10 No. 1 . 